\title{
Hubungan antara Profil Lipid, Ketebalan Tunika Intima Media Arteri Karotis dan Masa Ventrikel Kiri pada Remaja Obes
}

\author{
David Kaunang, Damaris Pali, Jeanette I.Ch.Manoppo \\ Bagian/SMF Ilmu Kesehatan Anak Fakultas Kedokteran Universitas Sam Ratulangi/RS. Prof. Dr. R.D. \\ Kandou, Manado
}

\begin{abstract}
Latar belakang. Obesitas pada anak merupakan salah satu faktor risiko penyakit kardiovaskular. Belum diketahui apakah profil lipid pada anak obes akan berpengaruh terhadap ketebalan tunika intima media (KIM) arteri karotis dan selanjutnya menyebabkan perubahan pada masa ventrikel kiri (MVK).

Tujuan. Mengetahui hubungan antara profil lipid, ketebalan tunika intima media arteri karotis dan massa ventrikel kiri pada remaja obes.

Metode. Dilakukan penelitian observasional analitik dengan metode potong lintang terhadap 37 remaja obes berusia 13-18 tahun dari bulan November 2013- Februari 2014. Kriteria eksklusi adalah obesitas dengan penyakit penyerta dan obesitas endogen. Pemeriksaan profil lipid yaitu kolesterol total, LDL, HDL dan trigliserida. Penilaian KIM arteri karotis dan MVK dilakukan dengan ekokardiografi. Analisis deskriptif untuk menganalisis karakteristik dan analisis korelasi menggunakan uji Pearson.

Hasil. Kadar rerata kolesterol total 186,45 mg/dL, LDL 128,83 mg/dL, HDL 45,83 mg/dL, trigliserida $110,75 \mathrm{mg} / \mathrm{dL}$, KIM 0,67 mm, dan MVK 393 gr. Terdapat hubungan bermakna antara kadar HDL dengan KIM arteri karotis $(r=-0,338, p=0,02)$. Tidak didapatkan hubungan antara kadar kolesterol total, LDL dan trigliserida dengan KIM (secara berturut-turut $r=0,079, p=0,320 ; r=0,085, p=0,309 ; r=0,116, p=0,247$ ), dan tidak didapatkan hubungan antara KIM dan MVK $(r=0,109, p=0,261)$.

Kesimpulan. Semakin tinggi kadar HDL, semakin rendah ketebalan tunika intima media arteri karotis. Ketebalan tunika intima-media arteri karotis tidak berhubungan dengan masa ventrikel kiri.

Sari Pediatri 2015;16(5):319-24.
\end{abstract}

Kata kunci: profil lipid, intima media arteri karotis, masa ventrikel kiri, obes

\begin{abstract}
Alamat korespondensi:
DR. Dr. Erling David Kaunang, Sp.A(K). Bagian Ilmu Kesehatan Anak FK UNSRAT/RSU Prof,Dr.R.D.Kandou Manado Jl.Raya Tanawangko, Manado 95115, Sulawesi Utara. Telp.: (0431)821625. Fax (0431)859091, PO Box 66 Manado 95115. E-mail: drdavid kau nang@yahoo.com
\end{abstract}

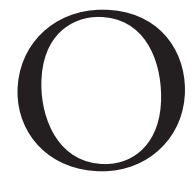
besitas pada masa anak memiliki komplikasi yang serius dan dihubungkan dengan peningkatan angka morbiditas dan mortalitas akibat penyakit kardiovaskular pada masa dewasa. ${ }^{1}$ Dampak utama obesitas meliputi 
gangguan pada tekanan darah, fungsi metabolisme, fungsi pernapasan, psikologis, adaptasi sosial, penyakit kardiovaskular, diabetes melitus, dan lain-lain. ${ }^{2}$ Obesitas pada masa kanak-kanak biasanya akan mempunyai efek atau pengaruh yang lebih buruk terhadap jantung dibanding jika obesitas didapat setelah usia dewasa. Hal ini disebabkan oleh karena efek samping obesitas ditentukan oleh berat dan lamanya obesitas. ${ }^{3,4}$

Beberapa penelitian melaporkan terdapat hubungan yang kuat antara perkembangan proses aterosklerosis dengan bertambahnya usia, indeks masa tubuh, peningkatan tekanan darah, dan kadar profil lipid. ${ }^{5}$ Pada anak ataupun remaja dengan obesitas harus dilakukan monitoring terhadap profil lipid karena dari beberapa penelitian sebelumnya didapatkan bahwa pada anak overweight dan obes cenderung terjadi dislipidemia. ${ }^{6}$ Peningkatan kadar kolesterol LDL merupakan salah satu prediktor peningkatan KIM arteri karotis pada remaja dan dewasa yang mempunyai hubungan kuat dengan terjadinya aterosklerosis dan risiko penyakit kardiovaskular. ${ }^{7}$ Pemeriksaan KIM arteri karotis merupakan pemeriksaan non-invasif dan merupakan petunjuk awal perubahan proses aterosklerosis. 7,8

Profil lipid yang utama adalah kolesterol total, LDL, HDL, dan trigliserida. Penelitian tentang pengaruh profil lipid terhadap peningkatan KIM arteri karotis dan MVK masih sangat terbatas. Oleh karena itu kami melakukan penelitian ini dengan tujuan mengetahui hubungan antara profil lipid, ketebalan tunika intima media arteri karotis dan massa ventrikel kiri pada remaja obes.

\section{Metode}

Penelitian observasional analitik dilakukan dengan pendekatan potong lintang untuk mengetahui hubungan antara profil lipid, KIM arteri karotis dan MVK pada remaja obes di Divisi Kardiologi Anak Departemen Ilmu Kesehatan Anak FK Universitas Sam Ratulangi Manado, mulai bulan November 2013- Februari 2014.

Subjek adalah anak remaja yang obes berusia 13-18 tahun yang bersekolah di SLTP dan SLTA di Kecamatan Tuminting, Manado. Kriteria eksklusi meliputi penyakit jantung bawaan, penyakit paru kronik, glomerulonefritis akut, sindrom nefrotik, hipertensi, diabetes mellitus dan obesitas endogen. Setelah orang tua setuju untuk ikut serta dan bersedia menandatangani formulir persetujuan dilakukan pencatatan identitas, pengukuran berat badan (BB), tinggi badan (TB), perhitungan indeks massa tubuh (IMT), dan pemeriksaan fisik. Dikategorikan obesitas bila IMT menurut umur dan jenis kelamin $\geq$ persentil 95 berdasarkan kurva center for disease control and prevention (CDC) tahun 2000. Kemudian dilakukan pemeriksaan laboratorium yaitu kadar kolesterol total, LDL, HDL dan trigliserida.

Pemeriksaan KIM arteri karotis dan MVK dengan menggunakan alat ekokardiografi kemudian diinterpretasi oleh spesialis anak konsultan kardiologi (penulis utama). Penilaian arteri karotis kanan dan kiri dilakukan dengan alat ultrasonografik Sonos 4500 dengan menggunakan transduser berfrekuensi $12 \mathrm{MHz}$. Bagian proksimal bulbus karotikus diidentifikasi terlebih dahulu dan segmen arteri karotis yang terletak $10 \mathrm{~mm}$ di sebelah proksimal dipakai sebagai tempat pemeriksaan. Pengukuran KIM dilakukan dari tepi atas garis ekogenik pertama sampai tepi pertama garis ekogenik yang kedua. Kedua hasil pemeriksaan tersebut (kiri dan kanan) dirata-ratakan. Pengukuran MVK dilakukan dengan 2 dimensi. Digunakan ekokardiografi M-mode sesuai kriteria The American Society of Echocardiography (ASE). ${ }^{?}$

Data dilaporkan dalam bentuk tabel distributif. Analisis korelasi antara kadar kolesterol total, LDL, HDL dan trigliserida, KIM dan MVK menggunakan uji Pearson dan regresi linier sederhana, nilai signifikansi yang digunakan adalah $\mathrm{p}<0,05$. Data dalam penelitian ini diolah dengan program SPSS versi 22. Penelitian ini telah mendapat persetujuan dari Komite Etik FK UNSRAT.

\section{Hasil}

Didapatkan 37 remaja obes, 15 anak laki-laki dan 22 anak perempuan. Karakteristik dan nilai statistik deskriptif sampel tertera pada Tabel 1.

Pada analisis korelasi Pearson, hubungan antara fraksi lipid dan KIM didapatkan hubungan yang bermakna, hanya kadar kolesterol HDL-semakin tinggi kadar HDL maka semakin rendah KIM. Hasil selengkapnya hubungan profil lipid dan KIM tertera pada Tabel 2. Pada analisis antara KIM dan MVK juga tidak didapatkan hubungan ( $r=0,109$, $\mathrm{p}=0,261)$. 
Tabel 1. Karakteristik subjek

\begin{tabular}{lcccc}
\hline Variable & Rerata & SB & Median & IK95\% \\
\hline Umur laki-laki (tahun) & 15.13 & 1,50 & 16,00 & $14,29-15,96$ \\
Umur perempuan (tahun) & 15,45 & 1,29 & 16,00 & $14,87-16,03$ \\
Tinggi badan (cm) & 159,21 & 9,22 & 159,0 & $156,30-162,49$ \\
Berat badan (kg) & 83,22 & 15,83 & 79,50 & $78,51-89,02$ \\
IMT $\left(\mathrm{kg} / \mathrm{m}^{2}\right)$ & 33,10 & 3,40 & 33,20 & $32,11-34,41$ \\
Kolesterol total (mg/dL) & 186,45 & 31,58 & 183,00 & $175,92-196,98$ \\
LDL (mg/dL) & 128,83 & 32,06 & 123,00 & $118,14-139,52$ \\
Trigliserida (mg/dL) & 110,75 & 40,38 & 106,00 & $97,29-124,22$ \\
HDL (mg/dL) & 45,83 & 9,47 & 45,00 & $42,67-48,99$ \\
KIM (mm) & 0,67 & 0,72 & 0,15 & $0,437-0,920$ \\
MVK (gram) & 393,00 & 186,17 & 351,00 & $330,92-455,07$ \\
\hline
\end{tabular}

Tabel 2. Hubungan fraksi lipid dengan KIM

\begin{tabular}{lcc}
\hline Fraksi lipid & Nilai $\mathrm{r}$ & Nilai $\mathrm{p}$ \\
\hline Kolesterol total & 0,079 & 0,320 \\
Kolesterol LDL & 0,085 & 0,309 \\
Kolesterol HDL & $-0,338$ & 0,020 \\
Trigliserida & 0,116 & 0,247 \\
\hline
\end{tabular}

\section{Pembahasan}

Obesitas telah diketahui merupakan faktor risiko utama tingginya angka morbiditas dan mortalitas pada penyakit kardiovaskular. ${ }^{2}$ Pada anak dan remaja obes, abnormalitas jantung dapat dideteksi dengan ekokardiografi yang dapat mendeteksi gejala awal hipertrofi dan disfungsi ventrikel. ${ }^{10}$

Beberapa penelitian sebelumnya melaporkan hubungan yang kuat antara obesitas dengan risiko terbentuknya aterosklerosis dini. Terbentuknya aterosklerosis dihubungkan dengan beberapa prediktor pada obesitas seperti adiposit, sindrom metabolik, profil lipid, dan resistensi insulin. ${ }^{8,11}$ Aterosklerosis subklinis dapat dideteksi dengan pemeriksaan yang non invasive, yaitu dengan pengukuran KIM arteri karotis. ${ }^{11}$

Pengambilan sampel dilakukan pada remaja berusia 13-18 tahun karena pada umur tersebut, berdasarkan penelitian sebelumnya, terjadi peningkatan prevalensi obesitas. Menurut data The National Health and Nutrition Examination Survey (NHANES), pada tahun 1976-1980, prevalensi obesitas anak usia 6-11 tahun mengalami peningkatan dari $6,5 \%$ menjadi $18,0 \%$. Sementara itu, pada tahun 2009-2010, pada usia 12-19 tahun, obesitas meningkat dari 5,0\% menjadi $18,4 \%$ pada periode yang sama. ${ }^{12}$ Sejalan dengan penelitian sebelumnya, penelitian kami mendapatkan remaja obes laki-laki lebih sedikit dari pada perempuan. ${ }^{13,14}$ Penelitian lain mendapatkan laki-laki lebih banyak dibandingkan perempuan, tetapi perbedaan tersebut tidak bermakna secara statistik. ${ }^{15,16}$ Menurut Steinbeck, ${ }^{17}$ pada anak laki-laki, obesitas lebih banyak terjadi dibandingkan perempuan. Pada anak perempuan, akan terjadi peningkatan lemak tubuh sejak usia 4 tahun. Dengan demikian, mereka mempunyai lemak tubuh yang lebih banyak dari pada anak laki-laki, tetapi peningkatan ini akan melambat setelah memasuki masa remaja. Sebaliknya, anak lakilaki berkembang terus sampai usia dewasa muda.

Kami mendapatkan rerata kolesterol total, kolesterol LDL, trigliserida, dan HDL pada remaja obes masih dalam batas normal. Hasil yang sama juga didapatkan oleh peneliti sebelumnya. , 10,15,18 Perubahan profil lipid cenderung terjadi pada individu dengan obesitas abdominal. Pada obesitas abdominal, terjadi peningkatan lipase hepar yang menyebabkan peningkatan trigliserida pada LDL dan HDL sehingga terjadi peningkatan LDL dan penurunan HDL..$^{18,19}$

Kami juga mendapatkan nilai rerata KIM arteri karotis $0,67 \mathrm{~mm}$ pada remaja obes. Penelitian sebelumnya juga mendapatkan hasil yang tidak jauh berbeda, yaitu $0,60 \mathrm{~mm}$ dan $0,67 \mathrm{~mm} .5,20$ Sampai saat ini, memang belum ditentukan cut off nilai KIM pada anak. Beberapa penelitian, yang membandingkan KIM pada remaja obes dengan remaja dengan berat badan normal sebagai kontrol, mendapatkan rerata KIM pada remaja obes berbeda bermakna dengan remaja yang tidak obes. ${ }^{8,15,16}$ Pada obesitas, terjadi 
peningkatan deposit lemak. Akumulasi lemak, pada sel endotel, akan menyebabkan disfungsi sel endotel yang merupakan proses awal terjadinya aterosklerosis. Aterosklerosis pada dasarnya merupakan suatu kelainan yang terdiri atas pembentukan fibrolipid fokal di dalam bentuk plak-plak yang menonjol atau penebalan yang disebut ateroma yang terdapat di dalam tunika intima dan pada bagian dalam tunika media. Plak terbentuk dari kelebihan kolesterol serta zat-zat yang mengalir dalam pembuluh darah, seperti sel-sel radang, protein, dan kalsium. ${ }^{6}$ Peningkatan KIM arteri karotis merupakan petanda awal terjadinya aterosklerosis. ${ }^{11}$

Kami mendapatkan nilai rerata MVK 393 gram. Hasil tersebut lebih besar dari pada penelitian sebelumnya-pada 91 remaja obes di Nigeria yang mendapatkan rerata MVK $(187,46 \pm 38,19)$ gram. ${ }^{9}$ Namun, rerata BMI penelitian tersebut (rerata BMI $21,3 \pm 4)$ lebih rendah dari pada penelitian kami.

Hipertrofi ventrikel kiri merupakan salah satu karakteristik adaptasi jantung pada obesitas. Peningkatan lemak tubuh total berhubungan dengan peningkatan metabolisme, cardiac output, dan volume total darah. Perubahan sirkulasi tersebut menyebabkan perubahan geometri dan dilatasi ruang jantung yang sering didapatkan pada obesitas. Volume plasma yang meningkat akan menyebabkan volume overload dan peningkatan curah jantung. Curah jantung menaikkan curah sekuncup dan pada akhirnya akan menyebabkan dilatasi ventrikel kiri. Dilatasi ventrikel kiri akan menyebabkan dinding ventrikel kiri makin tegang dan merupakan faktor predisposisi meningkatnya massa miokardial dan hipertrofi ventrikel kiri. ${ }^{2,11}$

Tidak didapatkan hubungan antara kadar kolesterol total, LDL, dan trigliserida dengan KIM arteri karotis, tetapi terdapat hubungan negatif antara kadar HDL dan KIM (r=-0,338,p=0,020). Sampai saat ini, hubungan antara profil lipid dengan KIM arteri karotis memang masih kontroversi. Beberapa penelitian mendapatkan hasil yang sama dengan penelitian kami, ${ }^{21,22}$ sedangkan penelitian di Turki mendapatkan kolesterol total, LDL, dan trigliserida berhubungan positif dengan peningkatan KIM dan HDL berhubungan terbalik dengan peningkatan KIM. ${ }^{15}$ Penelitian lain yang juga dilakukan di Turki, dengan sampel remaja dengan obesitas abdominal, mendapatkan hubungan bermakna antara trigliserida dan KIM, tetapi tidak ada perbedaan antara kolesterol total, LDL, dan HDL. ${ }^{19}$ Profil lipid akan berpengaruh terhadap risiko penyakit kardiovaskular, terutama jika bersamaan dengan hipertensi, resistensi insulin, diabetes melitus tipe 2, merokok, adanya riwayat keluarga, dan rendahnya aktifitas fisik. ${ }^{9,18}$

Kolesterol HDL merupakan lipoprotein yang beredar dalam sirkulasi yang pada umumnya berfungsi atheroprotective. Peran HDL membawa kolesterol dari sel ke hati dan dapat mengangkut kolesterol dari jaringan tepi, termasuk plak atherosklerotik, untuk diedarkan kembali atau dibuang dalam bentuk asam empedu. Proses ini disebut reverse cholesterol transport. ${ }^{23}$ Peran HDL meningkatkan pengeluaran kolesterol dari magrofag. Selain itu, HDL juga berperan penting sebagai anti inflamasi dan efek antioksidan. Hal tersebut dapat menjelaskan hubungan antara HDL dan KIM pada anak prepubertas yang memberikan hubungan relatif antar kadar lipid dengan dinding arteri pada usia tersebut. ${ }^{24}$ Hubungan antara kadar HDL yang rendah peningkatan ketebalan KIM didapatkan hasil yang konsisten pada beberapa penelitian pada usia dewasa muda. ${ }^{21,23}$ Kolesterol LDL membawa kolesterol dari hati ke sel. Kadar kolesterol LDL yang tinggi akan memicu penimbunan kolesterol di sel yang menyebabkan munculnya atherosclerosis (pengerasan dinding pembuluh darah arteri) dan penimbunan plak di dinding pembuluh darah sehingga menyebabkan ganggguan pada fungsi endotelial. ${ }^{23}$ Kadar kolesterol LDL yang tinggi dan kadar kolesterol HDL yang rendah merupakan faktor risiko penyakit kardiovaskular yang berdiri sendiri. ${ }^{23,24}$

Penelitian kami tidak mendapatkan hubungan antara KIM dengan MVK. Beberapa penelitian sebelumnya, pada remaja obes dengan ataupun tanpa hipertensi dengan nilai profil lipid yang memenuhi kriteria dislipidemia, mendapatkan hasil yang bermakna hubungan antara KIM dengan MVK. ${ }^{16,25}$ Sampel penelitian kami adalah remaja obes yang tidak hipertensi (normotensi) dan kadar nilai profil lipid yang masih dalam batas normal tinggi, tetapi belum memenuhi kriteria dislipidemia. Kami ingin melihat pengaruh profil lipid terhadap KIM dan MVK tanpa ada pengaruh dari faktor lain.

Keterbatasan penelitian ini adalah desain penelitian cross sectional sehingga tidak dapat mengevaluasi faktor risiko lain yang menyebabkan peningkatan KIM dan MVK. Faktor lama terpapar dengan obes tidak diteliti karena lama terpapar dengan obes juga berpengaruh terhadap peningkatan KIM dan massa ventrikel kiri. Pada penelitian ini, ditanyakan sejak kapan anak tersebut mengalami obes, tetapi jawaban yang diberikan 
tidak jelas karena hanya berdasarkan mulai berat badan naik. Dengan demikian, tidak dapat diketahui status gizi anak tersebut pada saat itu, apakah anak sudah obes atau overweight. Berdasarkan hal tersebut maka perlu dilakukan penelitian lanjutan dengan desain kohort prospektif untuk menilai peningkatan KIM dan MVK. Dari penelitian kami disimpulkan kadar kolesterol HDL yang rendah berhubungan dengan ketebalan tunika intima media arteri karotis. Ketebalan tunika intima media arteri karotis tidak berhubungan dengan massa ventrikel kiri.

\section{Daftar pustaka}

1. Lechleitner M: Obesity and the metabolic syndrome in the elderly-a mini-review. Gerontology 2010;54:2539.

2. Steinberger J, Daniels SR. Obesity, insulin resistance, diabetes, and cardiovascular risk in children. An American Heart Association scientific statement from the atherosclerosis, hypertension, and obesity in the young committee (council on cardiovascular disease in the young) and the diabetes committee (council on nutrition, physical activity, and metabolism). Circulation 2009; 107:1448-53.

3. Dehghan M, Danesh NA, Merchant AT. Childhood obesity, prevalence and prevention: Review. Nutr J 2005;4:24-8.

4. Wang Y, Beydoun AM. The obesity epidemic in the United States-gender, age, sosioeconomic, and geographic characteristic: A systematic review and metaregresion analysis. Epidemiol Rev 2007;29:6-28.

5. Wunsch R, Sousa G, Toschke AM. Intima-media thickness in obese children before and after weight loss. Pediatrics 2006;118:2334-8.

6. Klop B, Elte JW, Cabezas MC. Dyslipidemia in obesity: mechanisms and potential targets. Nutrients 2013;5:1218-40.

7. Maher V, O’Dowd M, Carey M, Markham C, Byrne A, Hand E. Association of central obesity with early carotid intima-media thickening is independent of that from other risk factors. Int J Obes 2009;33:136-43.

8. Reinehr T, Kiess W, Sousa G, Wagner BS, Wunsch R. Intima media thickness in childhood obesity: relations to inflammatory marker, glucose metabolism, and blood pressure. Metabolism 2006;55:113-8.

9. Amadi C, Mbakwem A, Oke A, Ajuluchukwu J. Left ventricular mass of normotensive adolescent progeny of
Nigeria hypertensives. Intern J Cardiol 2010;10:1-10.

10. Ghanem S, Mostafa M, Ayad S. Early echocardiography abnormalities in obese children and adolescent and reversibility of these abnormalities after significant weight reduction. J Saudi Heart Association 2010;22:13-8.

11. Sameer K. Mehta, J. Eduardo Rame, Amit Khera, Sabina A. Murphy, dkk. Left ventricular hypertrophy, subclinical atherosclerosis, and inflammation. Hypertension 2007;49:1385-91.

12. Fryar CD, Carroll, MD, Ogden, CL. Prevalence of obesity among children and adolescents: United States, Trends 1963-1965 Through 2009-2010. The National Health and Nutrition Examination Survey (NHANES). September 2012. Diakses pada 16 Maret 2014. Diunduh dari: http://www.cdc.gov/nchs/data/hestat/obesity_child_09_10/ obesity_child_09_10.pdf.

13. Friberg P. Johnsson AA, Ambring A, Arheden RA, Framme J, Johansson A, dkk. Increased left ventricular mass in obese adolescents. Europ Heart J 2004;25:98792.

14. Avelar E, Cloward TV, Walker JM, Farney RJ, Strong $\mathrm{M}$, Robert C, dkk. Left ventricular hypertrophy in severe obesity: Interactions among blood pressure, nocturnal hypoxemia, and body mass. Hypertension 2007;49:349.

15. Simsek E, Balta H, Balta Z, Dallar Y. Childhood obesityrelated cardiovascular risk factors and carotid intimamedia thickness. Turk J Pediatr 2010;52:602-11.

16. Stabouli S, Kotsis V, Karagianni C, Zakopoulos N, Konstantopoulos A. Blood pressure and carotid artery intima-media thickness in children and adolescents: the role of obesity. Hellenic J Cardiol 2012;53:41-7.

17. Steinbeck K. Childhood obesity: consequences and physical and psychosocial complications. Dalam: Kopelman PG, Caterson ID, Dietz WH, penyunting. Clinical obesity in adults and children. Massachusetts: Blackwell Publishing;2005.h.231-48.

18. Atikah FD. Efek intervensi diit dan aktifitas fisik terhadap profil lipid anak dengan obesitas. Tesis. Medan: Bagian Ilmu Kesehatan Anak Universitas Sumatera Utara; 2007. (Diakses pada16 Maret 2014). Diunduh dari: http://repository.usu.ac.id/bitstream/123456789/6287/1/ Fatimah1.pdf.

19. Lim SM, Kim HC, Lee HS, Lee JY. Association between blood pressure and carotid intima-media thickness. J Pediatr 2009; 154:667-71.

20. Ayer JG, Harmer JA, Nakhla S, Xuan W, Martin KC, Raitakari OT, dkk. HDL-cholesterol, blood pressure, and asymmetric dimethylarginine are significantly associated 
with arterial wall hhickness in children. Arterioscler Thromb Vasc Biol 2009;29:943-9.

21. Hariyanto D, Madiyono B, Syarif DR, Sastroasmoro S. Hubungan ketebalan tunika intima media arteri carotis dengan obesitas pada remaja. Sari Pediatri 2009;113:15967.

22. Hacihamdioglu B, Okutan V, Yozgat V. Abdominal obesity is an independent risk factor for increased carotid intima-media thickness in obese children. Turk J Pediatr 2008;53:48-54

23. Shepherd J. The role of the exogenous pathway in hypercholesterolaemia. Eur Heart J Supplements 2001;3:219.

24. Briel M, Gonzalez IF, John J, Karanicolas PJ, Akl EA, Ping W, dkk. Association between change in high density lipoprotein cholesterol and cardiovascular disease morbidity and mortality: systematic review and metaregression analysis. BMJ 2009;338:92.

25. Teixeira PJ, Sardina LB, Going SB, Lohman TG. Total and regional and serum cardiovascular disease risk factors in lean and obese children and adolescents. Obes Res 2001;9:432-42. 